Government Departments by the central or regional authority before transmission to local authorities, if local planning schemes are not to be delayed and confused. He reiterates with Mr. Gibson the importance of a local planning authority or joint committee deciding on the optimum size and population of a town before planning for increased industrial activity. Expansion beyond that size should be by means of arjjacent satellite or independent new communities within the region, each surrounded by a green belt.

The question of the optimum size of towns is one of the major problems on which further research is required. Obviously it may vary in accordance with physical limitations, the character and function of the town, the labour conditions, possible services, strategic situation and population required to support cultural activities, etc., and the analysis in the P E P report requires extension to some practical conclusion. The maximum density of development for urban areas, especially in residential units, is another matter in which further guidance is required, while the relation of agricultural to other industries established in rural districts needs investigation in several respects. The possibility of a further decrease of agricultural workers in Britain after the War, due to scientific and mechanized methods of farming and as a part of Imperial agricultural policy, must be seriously considered both in its effect on the vitality and mortality statistics and in relation to food policy and possible changes in production such as extended market gardening. Equally we have to consider the possibility of stabilizing and revitalizing rural community life by the introduction of selected light industries in villages, and the ways and means of safeguarding the benefits in health which have already flowed from the closer contact through evacuation of town workers with rural life.

Prof. J. H. Jones advocated the immediate establishment of regional boards, under the chairmanship of the Civil Defence Commissioners, to control the location of industry, and urged that the Government should decide whether the present Ministry of Works and Buildings is to be the effective Ministry of Reconstruction or to be superseded. Dr. Robson, in stressing the advantages of immediate planning to the war effort, holds that industry is capable of more control in its location than Prof. Jones suggested.

There can be no doubt that there are wide fields in which the planning of post-war Britain and the research and technique involved in reconstruction could be undertaken now with direct advantage to our war effort, apart altogether from the effect on public morale. There is much educational work to be undertaken, not merely of the general public, but also post-graduate education in such fields as organic planning, quantitative study of zoning areas, factorybuilding, shopbuilding, leasing and rent-fixing, control of use and design-aspects and techniques of town-building which, as Mr. F. J. Osborn pointed out, are not adequately covered in present townplanning education. There is also the vital contribution of the Building Research Station in regard to the use of new materials of construction as well as in matters of design, and here again research must be linked up with the development of new techniques and much far-reaching educational work.

\title{
CRUSTAL STRUCTURE OF NEW ZEALAND
}

\begin{abstract}
$\mathrm{K}$. E. BULLEN states that the progress of instrumental seismology has been slower in New Zealand than in a number of other earthquake regions, and it was not until the present decade that the identification of phases other than the normal $P$ and $S$ could be made in the records of near earthquakes (K. E. Bullen, "The Crustal Structure of the New Zealand Region as inferred from Studies of Earthquake Waves", Proc. Sixth Pacific Science Congress, 1939). The subsequent studies of the crustal structure of the New Zealand region have been subject to a number of special difficulties, of which some, but not all, have since been resolved or modified.

These difficulties centre chiefly around the considerable uncertainties in the determination of epicentres and origin times of many of the earthquakes which have shown phases in addition to $P_{n}$ and $S_{n}$. Epicentres are in general best determined from the absolute arrival times of $P_{n}$ at a sufficient number of stations, but until recently Wellington and Christchurch were the only stations the absolute time of which could be relied upon for such a purpose. This has necessitated recourse to $P_{n}-S_{n}$ intervals with the attendant difficulties of the accurate identification of the onset of $S_{n}$. There were doubts also concerning the normal $P$ velocity immediately below the crustal layers, and therefore by implication in the corresponding $S$ velocity also. A step forward was taken by Bullen when the significance of the phase $S^{*}$ was recognized in New Zealand earthquakes, following a study of the aftershocks of the Hawke's Bay earthquakes of February 2, 1931. It would appear that
\end{abstract}

$S^{*}$ has been recorded more often than any other phase in New Zealand and that $S^{*}$ may sometimes be recorded when the normal $S_{n}$ is completely missed. A revision of the analysis of the Wairoa earthquake of September 15, 1932, and of the Pahiatua earthquake of 1934 has led to further improvement. Statistical methods have been used wherever possible.

The new epicentre of the Wairoa earthquake was considered so satisfactory that new travel-time curves were prepared which, Bullen believes, approximate to the best results obtainable for the New Zealand region on the data so far available. The data refer particularly to that part of New Zealand which lies between latitudes $38 \cdot 5^{\circ} \mathrm{S}$. and $43 \cdot 5^{\circ} \mathrm{S}$. From these data $P^{n}$ up to $4^{\circ}$ has a velocity of $8 \cdot 1 \mathrm{~km}$. $/ \mathrm{sec}$. though the normal $7.8 \mathrm{~km}$. $/$ sec. fits nearer $6^{\circ}$. There are signs that $P^{*}$ is double with velocities 6.55 and $6.0 \mathrm{~km}$. $/ \mathrm{sec}$. $P_{\mathrm{s} \cdot 0}$ and $S_{3 \cdot 0}$ have additionally been recognized, the former making $S_{n}$ difficult to recognize at some stations. $P_{5 \cdot 0}$ has also been recognized by geophysical prospectors in New Zealand and may correspond to travel paths through greywacke, which occurs abundantly in the region between Wairoa and Wellington.

In conclusion, it is suggested by Bullen that the structure may be: (1) uppermost layer, perhaps a greywacke for a good part of the region, thickness $5-10 \mathrm{~km}$. with velocity of $P 5 \cdot 0 \mathrm{~km}$. $/ \mathrm{sec}$. and $S 3.0 \mathrm{~km} . / \mathrm{sec}$; (2) granitic layer, $4 \mathrm{~km}$. thick with velocity of $P 5 \cdot 5 \mathrm{~km} . / \mathrm{sec}$; (3) intermediate layers, $10-20 \mathrm{~km}$. thick altogether with velocities of $P 6 \cdot 0,6 \cdot 3,6 \cdot 5$ and $7 \cdot 0 \mathrm{~km}$./sec. and in the lower 
part $S 3.7 \mathrm{~km} . / \mathrm{sec}$; (4) lower layer dunite with base uncertain, velocity of $P 7 \cdot 8$ (?) $\mathrm{km} . / \mathrm{sec}$. and $S 4.4 \mathrm{~km}$./sec. This varies somewhat from the European structure, chiefly in having a thinner granitic layer and a thicker intermediate layer than Europe. The phase $P_{6 \cdot 0}$ may correspond to the phase $P_{Y}$ in California, and it is suggested that there may be some resemblance between the crustal structures of New Zealand and Japan.

\section{PLANTS USEFUL AND ORNAMENTAL}

$\mathrm{U}^{\mathrm{N}}$

NLESS he be a professed systematist, the modern botanist, newly arrived in the tropics, as also the horticulturist and agriculturist, may well find himself bewildered and dismayed, as well as bewitched, by the diversity and profusion of the vegetable forms which everywhere greet the eye. Those first encounters, indeed, provide a pleasure not entirely devoid of pain; they force a realization of the small knowledge that one so often brings to a vast subject. Such local works as afford simple and direct guidance in the identification of the more common genera and species are therefore of great value and should be appreciated accordingly.

In this category is the volume just issued by R. $O$. Williams and R. O. Williams, jun. ("The Useful and Ornamental Plants of Trinidad and Tobago", third edition, Government Printers, Trinidad), the original edition having been published by W. G. Freeman and R. O. Williams in 1927 and a second in 1928. The object, in the first instance, was to give information about native and introduced plants possessing interest because of their useful and ornamental qualities. Actually, a brief random sampling shows that the title errs on the side of modesty, for many plants, not essentially useful or ornamental, but of considerable botanical interest, are also described - a feature not only desirable in itself but also one which lends a fullness to the work.

The Colony, as the authors state, possesses many wild plants, prized for their economic or decorative value; and many plants have been successfully introduced from all parts of the world. "To obtain information on many of these is often difficult, even in a well appointed botanical library, entailing search through various standard works of reference, and often the agricultural, botanical and other publications of several other countries. To the person not so equipped the task is frequently a hopeless one." Thus appreciating the noed, the authors have successfully fulfilled their task. In this edition the lists of useful plants have been completely rearranged and keys have been provided to facilitate identifications. Cultural notes make a useful addition to plant descriptions and notes on crop plants have been brought up to date.

It is a pleasant occupation to make an excursion at random through such a work, where East meets West and where the denizen of the high woods comes to rest by the side of more everyday garden staples, but for the botanist the features of greatest interest are perhaps those sections where orchids, ferns, grasses, cycads, conifers, cacti and mangroves are treated as groups. At a glance the wealth of the Islands can be seen. Further, what is true of the major groups is true of the flora as a whole; the number of native and introduced plants possessing particular interest is surprising.

\section{FORTHCOMING EVENTS}

\author{
Thursday, June 5
}

Royal Society of Medicine (at 1 Wimpole Street, London, W.1) at 5.30 p.m.-Prof. Julian Huxley, F.R.S. : "Art as a Social Function" (Lloyd Roberts Lecture).

Chemical Society, Institute of Chemistry, and Society of Chemical Industry (Joint Meeting in the University Chemical Department, Bristol) at 6.30 p.m. -Prof. G. M. Bennett : "Liquid Crystals".

\section{APPOINTMENTS VACANT}

Lecturer in Mechanical Engineering-The Principal, Aston Technical College, Whitehead Road, Birmingham 6 (June 7 )

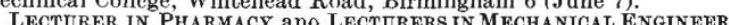
LECTURER IN PHARMACY ANO LECTURERS IN MECHANICAL ENGINEER Birmingham 1 (June 7 )

SENIOR LECTCRER IN THE DEPARTMENT OF ELECTRICAL ENGINEERING-The Principal, Heriot-Watt College, Edinburgh (June 9).

\section{REPORTS AND OTHER PUBLICATIONS}

\author{
(not included in the monthly Books Supplement)
}

Great Britain and Ireland Annual Report of the Oundle School Natural History Society. Pp.
20. (Oundle: Oundle School.)

Scientifle Proceedings of the Royal Dublin Society. Vol. 22 (N.S.) No. 38: The Vitamin D Requirements of the Growing Pig. By Brendan J. Senior. Pp. 379-386. 6d. Vol. 22 (N.S.), No. 39 : Studie on the Oxidising Action of Selenious Acid. 1: Organic Sulphu Compounds. By A. E. A. Werner. Pp. 387-392. 6d. (Dublin : Hodges, Catalogue of 20,554 Faint Stars in the Cape Astrographic Zone $-40^{\circ}$ to $-52^{\circ}$ for the Equinox of $1900^{\circ} 0$ giving Positions, Precessions, Proper Motions and Photographic Magnitudes derived from Photographs taken at the Royal Observatory, Cape of Good Hope, under the direction of Dr. H. Spencer Jones and Dr. J. Jackson; also Spectral Types classifled from Plates at the Harvard College Observatory, Cambridge, Mass., U.S.A., by Miss Annie J. Cannon. Pp. lvii 414. (London: H.M. Stationery Office.) 42s. net.

Observations made at the Royal Observatory, Greenwich, in the Year 1936, in Astronomy, Magnetism and Meteorolony, under the Year 1936, in Astronomy, Magnetism and Meteorology, under the direction of Dr. H. Spencer Jones. Pp. vii +A $78+$ B16 + Cix $+161+$ Reports on Progress in Physics. Vol. 7 (1940). General Editor: J. H. Awbery. Pp. iii +362. (London: Physical Society). 228. 6d. net.

\section{Other Countries}

Annals of the Carnegie Museum. Vol. 28, Art. 12: A New Crocodilian, Hassiacosuchus kayi from the Bridger Eocene Beds of Wyoming. By Charles C. Mook. Pp. 207-220 + plates 23-25. (Pittsburgh, Pa.: Carnegie Museum.)

Smithsonian Miscellaneous Collections. Vol. 99, No. 21: A New Shipworm from Panama. By Paul Bartsch. (Publication 3632.) Pp. ii $+2+1$ plate. (Washington, D.C.: Smithsonian Institution.)

Smithsonian Institution. Explorations and Field-Work of the Smithsonian Institution in 1940 . (Publication 3631.) Pp. v +100 . (Washington, D.C. : Smithsonian Institution.)

Annual Report of the Director of the Japan Institute for Science of Labour for 1939. By Dr. G. Teruoka. Pp. ii 14. (Tokyo: Japan Institute for Science of Labour.)
[85 United States Department of the Interior: Fish and Wildlife Service. Wildlife Circular 6: The House Rat. By James Silver. Pp. iv +18 . (Washing'on, D.C.: Government Printing Office.) 5 cents.

University of Bombay: Department of Chemical Technology. Annual Report 1939-40. Pp. 28. (Bombay: The University.) [95 Imperial Councii of Agricultural Research. Scientifle Monograph
No. 14: Further Studies on Cereal Rusts in India. By Dr. K. C. Mehta. Pp. vii $+224+12$ plates. (Delhi: Manager of Publications.) Mehta. Pp. vii $+224+12$ plates. (Delhi: Manager of Publications.)
6 rupees ; 98. $6 d$. 6 rupees; $98.6 d$. Stratigraphy of South Singhbaum. By Dr. J. A. Dunn. Pp. iv $+303-$ $370+$ ix + plates $33-37$. (Calcutta : Geological Survey of India.) 1.14 rupees; $28.9 d$.

Publications of the Observatory of the University of Michigan. Vol. 8, No. 5: The Spectrum of Nova Cygni III (1920). By Ralph B. Baldwin. Pp, 61-94+2 plates, Vol. 8, No. 6: The Francis C. McMath Memorial 24-inch Reflecting Telescope of the McMath-Hulbert Observatory. By Robert R. McMath. Pp. 95-102+6 plates. Vol. 8, No. 7 : Dimensions and Shape of the Andromeda Nebula. By Robley $\mathrm{C}$. Wiliams and W Albert Hiltner. $\mathrm{Pp}$ 103-106+1 plate. Mich. : University of Michigan.) 